Loading

The Journal of the Canadian Game Studies Association

\title{
The Role of Architecture in Constructing Gameworlds: Intertextual Allusions, Metaphorical Representations and Societal Ethics in Dishonored
}

\section{Anthony Zonaga and Marcus Carter}

Volume 12, Number 20, Fall 2019

URI: https://id.erudit.org/iderudit/1065898ar

DOI: https://doi.org/10.7202/1065898ar

See table of contents

Publisher(s)

Canadian Game Studies Association

ISSN

1923-2691 (digital)

Explore this journal

Cite this article

Zonaga, A. \& Carter, M. (2019). The Role of Architecture in Constructing Gameworlds: Intertextual Allusions, Metaphorical Representations and Societal Ethics in Dishonored. Loading, 12(20), 71-89.

https://doi.org/10.7202/1065898ar
Article abstract

In this article, we present a close analysis of the role that the steampunk industrial Victorian architecture in Dishonored (2012) has in constructing the player's experience and knowledge of the gameworld. Through various intertextual allusions and metaphorical representations, we argue the architecture works as an important storytelling element, contextualizing information that the player learns and conveying information about the game's main characters, similar to the ways that architecture is utilized in other visual media such as television and film. In addition, we also argue that the architecture in Dishonored plays a crucial role in conveying to the player information about the morals and values of the fictional society, key to the game's moral-choice gameplay.
Copyright Anthony Zonaga, Marcus Carter, 2019

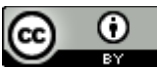

This document is protected by copyright law. Use of the services of Érudit (including reproduction) is subject to its terms and conditions, which can be viewed online.

https://apropos.erudit.org/en/users/policy-on-use/ 


\title{
The Role of Architecture in Constructing Gameworlds: Intertextual Allusions, Metaphorical Representations and Societal Ethics in Dishonored
}

\author{
Anthony Zonaga \\ Independent Scholar \\ aizonaga@gmail.com \\ Marcus Carter \\ The University of Sydney \\ aizonaga@gmail.com
}

\begin{abstract}
In this article, we present a close analysis of the role that the steampunk industrial Victorian architecture style in Dishonored (2012) has in constructing the player's experience and knowledge of the gameworld. Through various intertextual allusions and metaphorical representations, we argue the architecture works as an important storytelling element, contextualizing information that the player learns and conveying information about the game's main characters, similar to the ways that architecture is utilized in other visual media such as television and film. In this way we argue that the architecture in Dishonored plays a crucial role in conveying to the player information about the morals and values of the fictional society, key to the game's moral-choice gameplay.
\end{abstract}

\section{Author Keywords}

Architecture, Dishonored, gameworlds, societal ethics in games

\section{Introduction}

Recent trends towards transnarrative and transmedial worlds - in which a single imaginary world appears throughout a multitude of different creative media - has led to an emphasis being placed on the process of immersive world-building and the methods utilized to create "background richness and verisimilitude" (Wolf, 2014, pp. 2-3). In videogames, particularly those in the roleplay genre, enormous effort is placed in ensuring that the virtual gameworld feels and plays coherently. Design elements attributed to successful world-building range from: an 'accurate' physics engine; detailed mythologies and world-histories; the accents, reactions and costumes of non-player characters; and the music and soundscape of the virtual environment. A complex interplay between a broad variety of these elements is recognized as playing a role in establishing the "integrated whole" (Wolf, 2014, p. 192) of a gameworld, the backdrop against which any narrative elements of the game are played.

However, the role that game architecture plays in our experience of videogames is often merged with other aesthetic elements, in the study of a games' spatiality, or entirely overlooked by game 
scholars. This, we argue, is problematic, as the architecture of buildings and cities in games is integral to their experience, and game architecture frequently plays an important and affective role in building the imaginary worlds of videogames (Bonner, 2014). Rather than being conflated with other design or cultural representations in games, in this article we demonstrate how architecture - referring here to the design of the buildings and streetscapes - works in distinct ways to shape and inform the player's experience, particularly their knowledge of the game's imaginary world (Wolf, 2014). Our attention to game architecture is motivated and affirmed by the recent trend of game studios enlisting the consulting expertise of formally trained or practicing architects to create more authentic 3D environments, a role previously undertaken by level designers and art directors (see von Borries, Walz, \& Böttger, 2007, p. 132-133).

In this article, we present a close analysis of the architecture in the 2012 stealth action-adventure game Dishonored (Arkane Studios, 2012), unpacking the role that the game's steampunk industrial Victorian architecture has in constructing the player's experience and knowledge of the gameworld. Our results are presented along the three main themes that we identified. The first is how Dishonored's architecture draws on intertextual allusions (Krzywinska, 2008) to real-world architecture to inform the player's understanding of the gameworld and as a storytelling element. Secondly, we highlight how metaphorical representations are embedded in the game's architecture to convey important information about the game's main characters, similar to how architecture is utilized in other visual media such as television and film. Finally, we suggest that the game's architecture plays a crucial role in conveying to the player information about the morals and values of the fictional society of Dishonored. These societal ethics, we argue, have a profound impact on the ethical agency of the player within the gameworld (Sicart, 2009), and their experience of the ethical decision making that characterizes the Dishonored series (see also, Jørgensen, 2015). In the discussion and conclusion, we argue that these roles demonstrate how architecture in videogames functions as an integral aspect of the game, working to improve world-building and consequently the player experience. We further discuss how embodiment, architectural affordances and Dishonored's support of alternate playstyles can transform the player's relationship with the game's architecture, with insights and implication for future work.

\section{Related Works}

\section{Architecture in Videogames}

Work in architectural theory negotiates architecture as both a visual and spatial art form. Much of the attention that has been given to games in the context of architectural theory has emphasized the distinctive nature of virtual worlds and game worlds as spatial environments that can be navigated and interacted with (e.g., see Jenkins, 2001; Flynn, 2004; Golding 2013). In some ways, this attention reflects the early efforts of game studies to distinguish itself from literary or film theory through an increased attention to what distinguishes games from earlier media (Wesp, 2014). Contrary to this, the approach that we take in this paper is situated within traditions from film and television studies (Fear, 2000; Tobe, 2016) that examine architecture as a visual form, but (as we discuss later in the paper) this approach has limitations. As feminist scholars such as Elisabeth Grosz (2001) and Doreen Massey (1994) have previously highlighted, architectural space is deeply interrelated with the body, and thus where games are so specifically about the taking up of a new body in (virtual) spaces, the study of game architecture and gameworld should also account for the virtual embodiment of the player, and how this virtual 
embodiment is constructed by, and constructs, the gameworld.

However, limited prior work in game studies has focused on the architecture within a single videogame in close detail. Michael Nitsche (2008) has discussed the way that architecture can help "describe how a game world can gain significance and a quality or "place"” (p. 160), and Friedrich von Borries et al. (2007) present a compilation of over 180 essays, interviews, reviews and short statements by practitioners and theorists of architecture, urban design, game design and game studies. Von Borries et al. argue that interdisciplinary exchange between architecture and game design is mutually beneficial, suggesting that this would lead to "a new form of interactive space... in both virtual gamespaces and physical, architectural spaces" (pp. 11-13). Similarly, Steffen P. Walz (2010) proposes a gesture towards a 'ludic architecture': “an analytical and designedly understanding of contemporary play and games through the lens of architectural paradigms" (p. 1). Whilst this literature demonstrates a synthesis of various aspects of architecture and game design, they undertake a holistic approach towards the interrelationships between the fields of architecture, games, and play. As a result, each individual section or article draws general conclusions, only examining games/concepts briefly.

Closest to our work here, Marc Bonner (2014) has provided the foundation of an academic synthesis of architectural thought with game studies $(2014 ; 2015)$. He discusses theories from architecture that describe and help us understand the ways in which architecture in games - like 'real' architecture - uses architectural styles and forms to "refer or denote beyond their material entity to actual functions and internal contents" (2014, p. 3), highlighting how various architecture scholarship aligns with emerging theories and understandings in game studies. To demonstrate these alignments, Bonner provides brief analyses of the dystopic architectural styles in Half Life 2 (Valve Corporation, 2004), Deus Ex: Human Revolution (Eidos Montréal, 2011), and BioShock (2K Boston, 2007), emphasizing the ways that the architecture in these games works to "build up atmosphere and inform the player about optional actions and possible motion patterns" (p. 10). His analyses show how architecture in games "projects values onto plot, game world, or NPCs and initiates connections to the player's own emotions and memories from everyday life" (p. 10), demonstrating the value in closely analyzing game architecture and the role it plays in constructing gameworlds.

\section{Architecture and Gameworlds}

Yet, architecture is often ignored or overlooked in the breadth of academic work that focuses on analyzing and understanding gameworlds, understood here as the coherent and imagined ecological environment (Jørgensen, 2013, p. 80) that exceeds the narrative structures and interactive elements of games (Wolf, 2014). The gameworld supports, contextualizes, and influences the actions of the player (see also Björk \& Holopainen, 2005, pp. 56-57; Klastrup, 2009; Egenfeldt-Nielsen, Smith \& Tosca, 2008). In Building Imaginary Worlds, Mark Wolfe (2014) briefly recognizes architecture as one of the many facets of 'culture', which is one of several different world-building 'infrastructures', noting that as audience expectations became more sophisticated, "cultural design, in such areas as costume, architecture, vehicles, and so forth, had to be considered concretely ... as an integrated whole" (p. 182). Wolf also notes how real-world (or 'primary world') infrastructures are drawn on to make "connections to the audience's own lived experience and [for] establishing some degree of emotional realism" (p. 154) which in games can "suggest a larger world beyond the incomplete material available to an audience” (p. 197). Here, we'll argue, architecture plays a crucial, yet often overlooked, role. 
In writing about the imaginary fantasy world of World of Warcraft, Tanya Krzywinska (2008) acknowledges Markku Eskelinen's (2004) assertion that "spatiality is an important factor in computer games, but that very fact makes architecture... far more important to game scholars and designers than any travelogue or myth", but neither provided a detailed analysis. Krzywinska's (2008) study does further explicate how a game's imaginary world is constructed through intertextual allusions. In World of Warcraft's case, these are correspondences and references to pre-existing fantasy rhetoric, which she refers to as "mythic structures" (p. 126), but also real-world elements such magical revivalism and in-game festivals for Christmas and Halloween. These textual structures provide "a sense for the player of being in the world" ( $p$. 138), and "provide a rationale for the way the player character is assigned a particular, predetermined, morally and emotionally loaded history and identity" (p. 137). She extends this concept to the ruined architecture found in the game, which she suggests lends atmosphere and drama whilst providing visual cues to historical events and "the state of affairs" (p. 130). On this foundation, and in identifying this gap in current work, we set out to closely analyze the architecture of a single game to contribute a better understanding the relationship between architecture and world-building.

\section{Dishonored (2012)}

Dishonored is a single-player, first-person Role-Play Game (RPG), developed by Arkane Studios and released in 2012. It is set in the fictional, plague-ridden dystopian city of Dunwall, an industrial whaling city. The architecture of Dishonored is heavily inspired by the Victorian architecture of 19th century London and Edinburgh, synthesized with a steampunk aesthetic (see Tanenbaum, Tanenbaum, \& Wakkary, 2012). On the conception of Dunwall, visual design director and city architect Viktor Antonov (2012) explains that "[Arkane Studios] wanted to create a huge metropolis with style and personality... something that can't be identified as the past or the future, but as a parallel dimension... in this time, there is incredible technology as well as sublime machines and architectural styles" (Antonov, Mitton \& Baron, 2012).

Though the Empress of Dunwall - Jessamine Kaldwin - is portrayed as a benevolent ruler, the society of Dunwall is unquestionably dystopic as it is subject to significant social and economic stratification in which the lower classes are decimated by the plague, while the aristocracy continues to thrive in walled off sections of the city. The streets are patrolled by a supercilious City Watch, a militant religious faction, and thugs belonging to various criminal organizations. Two sequels, Dishonored 2 (2016) and Dishonored: Death of the Outsider (2017) are set in the same fictional universe.

The player assumes the role of Corvo Attano, a bodyguard to the Empress, and the game's narrative begins with her murder by assassins with supernatural abilities, capable of teleporting short distances and overcoming the player's ability to protect her. Corvo is framed for her murder and imprisoned, eventually escaping and taking on the role of an assassin in order to dismantle the group of conspirators who planned the Empress' murder and prove his innocence. The mysterious character known as 'The Outsider' gives the player-character access to a wide range of powerful magical abilities to achieve these goals. Corvo must also rescue Emily Kaldwin, heir to the throne, who is kidnapped to be exploited as a puppet ruler once she comes of age. Distinguishing Dishonored from other games in the single-player RPG genre, the game allows the player significant freedom in the methods in which they progress, both spatially and 
ethically, whilst constraining them to a linear narrative told through a series of nine 'missions'.

For instance, in the mission titled High Overseer Campbell, the player is given the objective of assassinating a target stationed in a heavily fortified complex and stealing his journal. Players have several options of how they navigate the environment to achieve this goal, such as crawling stealthily through the sewers, scaling the outer walls and climbing through a window, or simply walking through the front door after engaging and killing the guards in combat. While the instructions given to the player by the non-player character (NPC) Farley Havelock are prefaced by 'tonight, High Overseer Campbell dies by your hand', players can complete the mission in a variety of lethal, non-lethal and stealthy ways including brazenly engaging and killing him in combat, or stealthily poisoning his drink. Further exploration of the environment also points players towards the ritual of the Heretic's Brand, a method which completes the mission by stripping the target of his authority while leaving him alive. While this degree of freedom is afforded to the player, they must still operate within the framework of the game: the player must eliminate the target somehow in order to progress the narrative, and cannot, for example, abandon their role as an assassin to open a bakery.

It is possible to complete the entire game without killing a single person, which is linked closely to an in-game morality system named Chaos (which is largely unseen to the player, save for a note in end-of-mission summaries telling them if Chaos is high or low). Chaos affects the number of enemies in areas, the reaction of NPCs to Corvo, and the tone of the game's ending, and is influenced by the number of people killed by the player and various ethical choices they may make. Kristine Jørgensen (2015) claims that Dishonored "favours a low-chaos approach to the game, at the same time as it pulls the player towards justifying a certain degree of violence motivated by vengeance" (pp. 212-213). Players are confronted with the unethical actions of their targets before being afforded the ability to choose their fate. In this way Jørgensen argues that Dishonored is an "ambivalent game" (p. 223) which draws the player towards dark play, even if they set out to play morally. In our results, we argue that the architecture of Dishonored is linked closely with establishing the ethical ambiguity in player choices, as it conveys information to the player regarding the societal ethics of Dishonored which impacts their interactions with, and decisions within, the gameworld.

\section{Method}

Dishonored was chosen as the focus of this article due to the way that architecture features prominently in how the narrative of the game unfolds and how players traverse the environment. While its distinct and coherent dystopian architectural style is often praised in reviews of the game, we note that the emphasis on Dishonored's architecture is typical of games in the roleplay game genre. We analyze it here as a single critical case study (Yin, 2004, p. 38) which provides the opportunity to develop theory about architecture in games more broadly, which should be further tested and refined in future work in close analyses of architecture in other games. To gather data related to the architecture of Dishonored, the game was completed twice on PC, following either a low-Chaos or high-Chaos approach, while taking screenshots and video recordings of the game's architectural features. The 'Gamewise.co' walkthrough was used to ensure all areas were explored. This double-playthrough was conducted under the assumption that the game's architecture may change based on the player's ethical decisions, which turned out not to be the case. 
As prior work offers few analysis techniques for studying architecture in games, we have employed visual analysis techniques for studying architecture in film (see Fear, 2000; Tobe, 2016) as a guiding analytical framework. Through this approach, architecture is treated as a form of "visual shorthand" used by filmmakers (or game designers) to portray and convey codes of representation as well as prompts for our imaginations to imagine a whole from the image on the screen (Tobe, 2016, p. 1). However, the adoption of different play-styles for the purpose of completeness revealed additional insights into the relationship between player experience and game architecture, that exceeded the limits of visual analysis. Thus, while we approach the architecture in Dishonored from the perspective of visual analysis, our findings also begin to engage with the fact that the architecture of the game is both visual and spatial, and should also understood in relation with the player's embodied navigation through it. We return to the limitations of this method in the discussion in our reflections on future work.

\section{Results}

This close analysis of Dishonored's architecture highlighted three main roles that the game's steampunk industrial Victorian architecture plays in constructing the player's experience and knowledge of the gameworld. Here we present and discuss these in turn, beginning with: (1) the use of intertextual allusions (Krzywinska, 2008); (2) metaphorical representations about the game's main characters; and (3) the societal ethics of the gameworld.

\section{Intertextual Allusions}

The process of world-creation in games is "reliant on intertextual features for the generation of meaning and recognition" (p. 123). There are no gameworlds that do not utilize "allusions, correspondences and references" (p. 123) to the "real' or "primary world" (from Wolf, 2013), or to fictive worlds constructed in and for books, film and television for world-creation. Gameworld architecture similarly draws on existing precedents and architectural styles of the real-world for world creation. The following examples of architecture in Dishonored show how the game's developers attempt to draw on player knowledge of real-world architecture to inform their interpretation of gameworld architecture, imbuing it with meaning and working as a storytelling element to contextualize the player's situation and their interpretation of the gameworld.

\section{Coldridge Prison}

The first mission of the game requires the player to escape their impending execution by breaking out of Coldridge Prison, where Corvo has been imprisoned for six months after being falsely accused of murdering the Empress and conspiring to abduct her daughter Emily. Coldridge Prison is visible from Dunwall Tower (in which the prologue takes place), and vice versa, foreshadowing Corvo's imprisonment and providing a geographical point of reference for the player. Stripped of their weapons, there is seemingly no escape from the prison cell. The cracked walls of the cell extend upwards several stories while perspective causes them to claustrophobically close in above the player. Chiaroscuro lighting (strong contrasting light and dark areas) plays against the bars both above and ahead of the player, drawing attention to their imprisonment and emphasizing their helpless situation. 


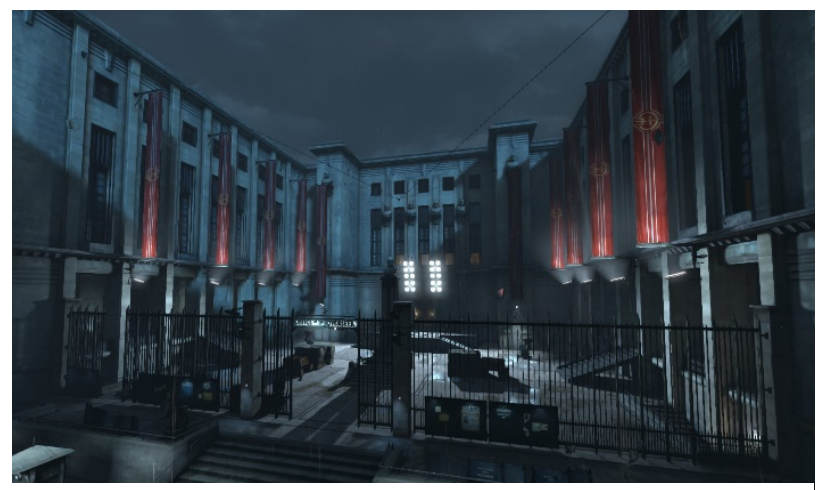

Figure 1 - The Office of the High Overseer

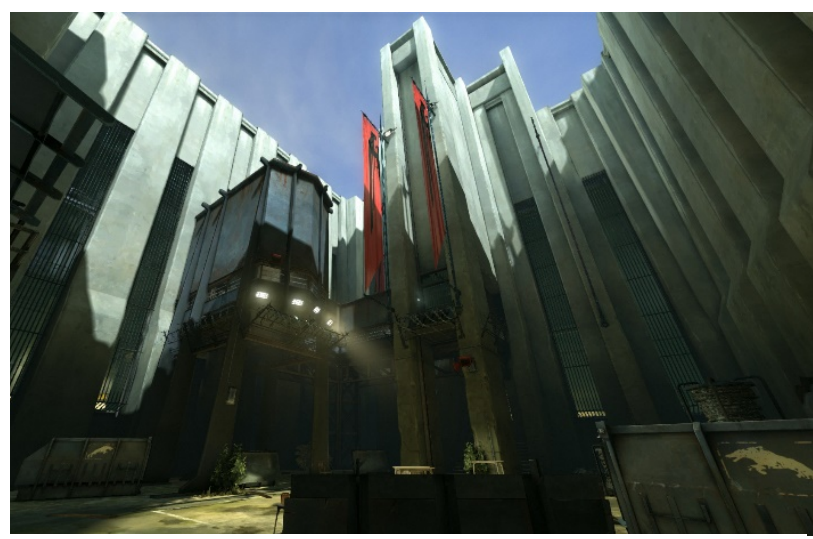

Figure 3 - An Internal courtyard of Coldridge Prison

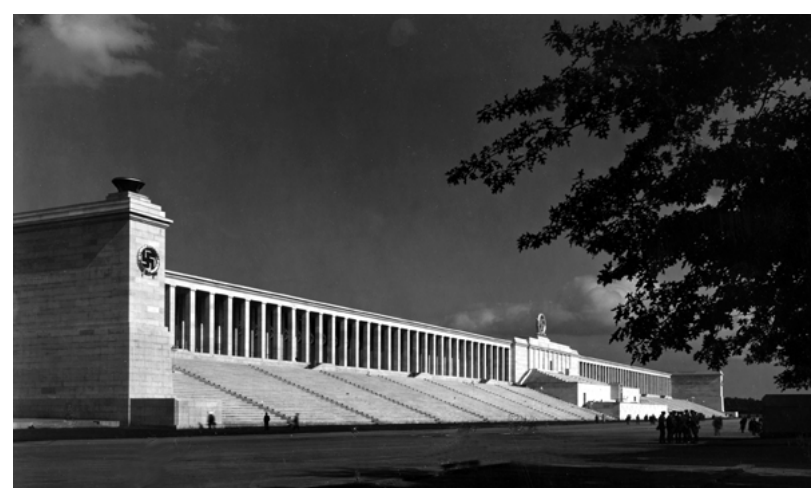

Figure 2 - The Zeppelin Grandstand, designed by Albert Speer, a part of the Nuremburg Rally

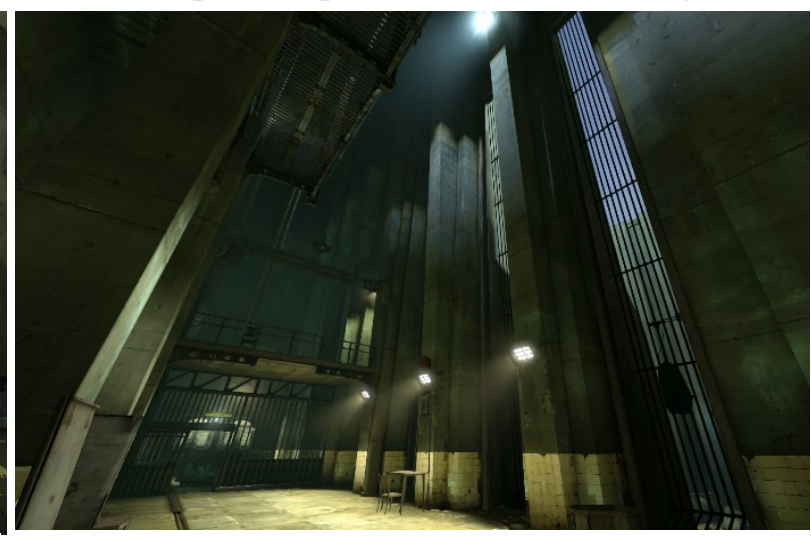

Figure 4 - An internal hallway in Coldridge Prison.

After breaking free from their cell with the aid of an unknown friend, the player must navigate through the prison, sneaking past or fighting patrolling guards. The prison is a distinctly vertical space in which articulated columns, walls, and barred windows lead the viewer's eyes upwards where they appear to disappear into the darkness. In an internal courtyard which is completely surrounded on all sides by the monotone, heavy masonry of the building's exterior (see Figure 3 ), sunlight cannot even reach the ground. The interior and exterior of the prison reference the oppressive, totalitarian architecture style most notably employed in Nazi buildings such as those designed by German architect Albert Speer (see Figures 1 \& 2). Daniel Grinceri (2016) describes the way that this architectural style - a distorted Neoclassicism - misappropriated traditional German ideals and historical aesthetics to express Nazi values (p. 96). Speer referred to the Nazi architectural style as "multiplied, altered, exaggerated, and sometimes distorted to the point of ludicrousness" (as cited in Grinceri, 2016, p. 111), clearly invoked by the hyperbolic verticality of the prison's building elements. This precedent of architectural style is experienced through the player's real-world knowledge, but also a wide breadth of fictional precedent that similarly borrows on this architectural style to depict harsh totalitarian governments. In Dishonored, the totalitarian architecture works intertextually to convey valuable information regarding the character's current predicament, wider implications about the state of society, and the potential ethics of their in-game choices whilst simultaneously providing an uninterrupted gameplay experience. In this way, architecture is working as a form of Wolf's (2014) 'secondary-world infrastructure', providing the scaffolding for players to imagine "a larger world 
beyond" the temporally, narratively, and interactively constrained interface of Dishonored ( $\mathrm{p}$. 197).

\section{The Office of the High Overseer}

In the mission High Overseer Campbell (discussed earlier), the player must infiltrate the headquarters of the ruthless religious zealots who are aggressively hostile to any supernatural abilities, such as those used by Corvo. The headquarters consist of a two storey U-shaped building with arms embracing an entrance courtyard (see Figure 1) and repurposed warehouse spaces at the rear. The main building comprises a number of highly functional spaces. On the ground floor, the lobby houses a formal gathering and worship area in the form of a double height space constructed of articulated solid masonry elements clad in decorative marble, directly contrasting with the dank crumbling interior of Coldridge. The architectural style draws heavily on early-1930s Modernist architecture evocative of the rise of nationalism, evidenced by its sheer scale, symmetry, and formal expression (though some ornamentation can still be found such as in the square coffers of the ceiling). The introduction of Modernist elements is reflective of the nature of the religious order itself: strict, disciplined and highly ordered. While the red tapestries serve as obvious allusions to Nazi flags, the oppressive Nazi architectural aesthetic of Coldridge Prison is replaced with an austere Fascist style which introduces one notable element: the horizontal line. While the verticality of Coldridge is certainly present in the office, the harsh formality of the religious order necessitates a more rigid architectural expression. These horizontals take the form of unembellished projected ledges supported by corbels, along with horizontal breaks in the fenestration to account for the second story of the building.

Furthermore, as an extension of the building's geometric aesthetic, the square is a prominent religious architectural signifier as it appears throughout the building as a repeated module in floor tiles, parquetry, coffers and fenestration. Principles of repeated proportion and geometry are featured heavily in real-world religious architecture to evoke a sense of sacred space (Skinner, 2009, p. 6-7); though in combination with the heavy corruption and oppressive nature of the Overseers seen through dialogue and narrative, the apparent sanctity of the abbey is twisted into the dystopian profane. Like Coldridge, the architecture works as an intertextual reference, drawing on the player's real-world knowledge and experience in order to convey specific information about the world. In this case it expands on the nature of the Abbey of the Everyman and its authority in the society of Dunwall, working like World of Warcraft's mythic structures to add coherence for a "thick text and a rich experience" (Krzywinska, 2008, p. 128). More than just a cult, it becomes apparent to the player through the architecture of the Office of the High Overseer that the Abbey is a pervasive and powerful force in the lives of all the city's inhabitants, contextualizing the other information they learn about the order through this mission. As with Coldridge Prison, intertextuality and infrastructure is utilized to evoke specific connotations through the game's architecture. Although the early-Modernist totalitarian architectural style is similar between the two settings, they convey different storytelling messages to the player through subtle variations in architectural design and quality.

\section{Metaphorical Representations}

In visual media such as television and film, metaphor is a filmic device used to emphasize specific ideas and enhance the audience's understanding of characters, objects, or plot devices (see Lamster, 2000, p. 143). Architectural metaphor is commonplace in film and is also relevant 


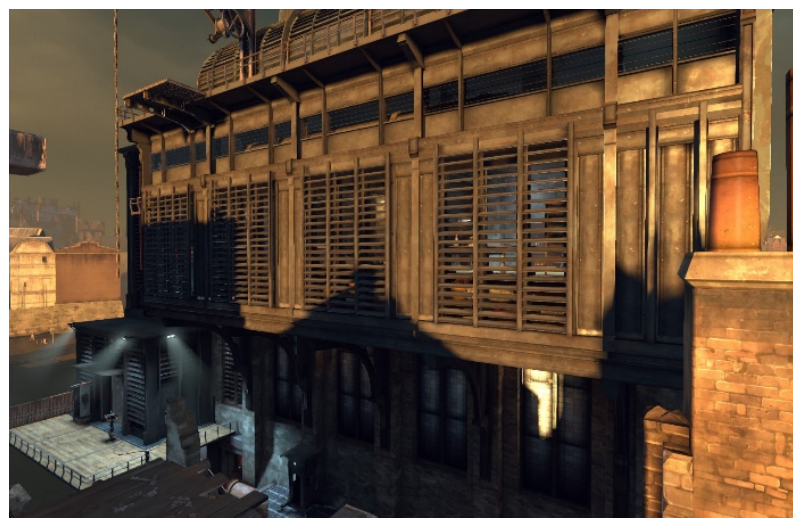

Figure 5 - The external façade of Sokolov's Safehouse. The steel structural addition is attached to the original brick façade by enormous metal corbels, casting it in shadow while the addition is allowed full solar access.

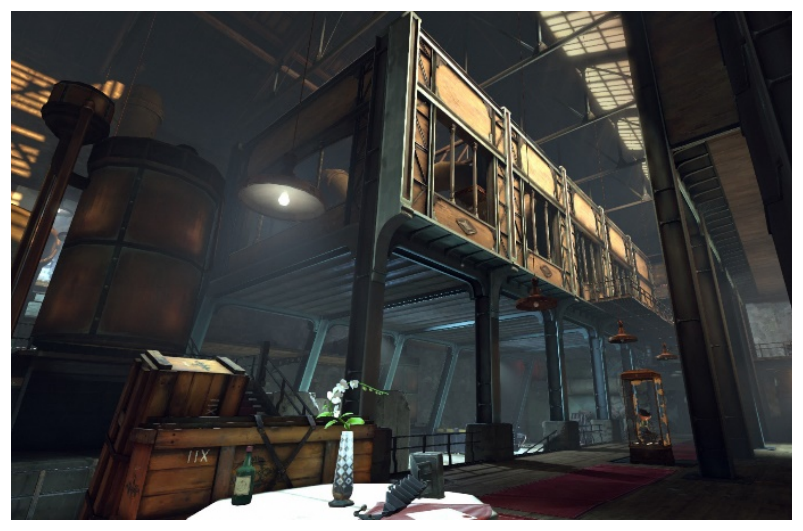

Figure 6 - The interior of Sokolov's Safehouse. The warehouse has been repurposed, and the new steel structure appears like a foreign life form tentatively hovering within the space.

in the context of our subsequent assertion that architecture is reflective of the morals of those who build and dwell within it. The following architectural examples in Dishonored demonstrate how architecture is used as visual metaphor for important characters to convey information about the game's main characters, similar to how architecture is utilized in other visual media.

\section{Kaldwin's Bridge and Sokolov's Safehouse}

In Dishonored's fourth mission, The Royal Physician, the player must abduct and interrogate Anton Sokolov, head of the Academy of Natural Philosophy and Royal Physician to the ruler of Dunwall. Sokolov is a prolific inventor responsible for developing the advanced military technology in Dunwall, as well as leading (unethical) research into a cure for the plague, based on archetypal historical figures such as Leonardo da Vinci, Nikola Tesla and Grigori Rasputin (Smith, 2016). In this mission the player must access Solokov's laboratory-turned-safehouse on a large bridge spanning the Wrenhaven River known as Kaldwin's Bridge, which - like the 'Old' London Bridge - houses residential buildings and warehouses along the bridge itself. In this mission the bridge is on lockdown, and the player must overcome many of Sokolov's whale oilpowered inventions, such as rail cars, floodlights, and the lethal Arc Pylon and Wall of Light security systems which instantly disintegrate trespassers. The safehouse itself is a repurposed warehouse, with cantilevered steel structures affixed to its façade (see Figure 5) which also permeate within the large interior space (see Figure 6).

The alterations to the traditional brick building have superseded its original purpose; it is no longer used in its industrial function but now serves to assist Sokolov to develop his new technologies. In this sense the architectural metaphor is drawn parallel to Sokolov himself and the role he plays within Dishonored's imaginary world; like the metal structures which engulf the outdated historical brick warehouses seen throughout the city, he is bringing Dunwall into a new age of technological advancement. This manipulation of Dishonored's architecture draws attention to the historical development of the city in its technological innovation, while at the same time characterizing the man who is bringing about this change. As a result, an attentive player is able to engage with the gameworld through not only explicitly embedded infrastructural knowledge, but also deeper and more evocative metaphorical analogies. 


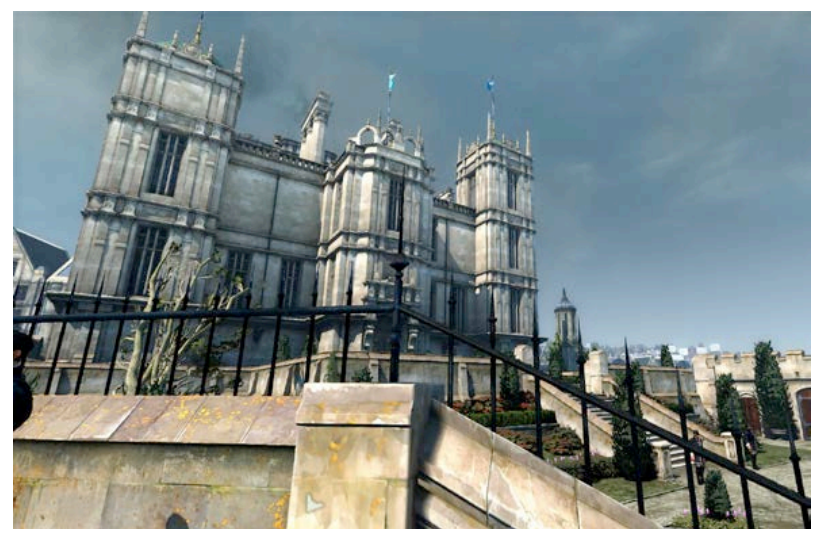

Figure 7 - Dunwall Tower in the opening prologue of the game. The player is unable to progress past the steel fence, but is allowed to explore a small area outside.

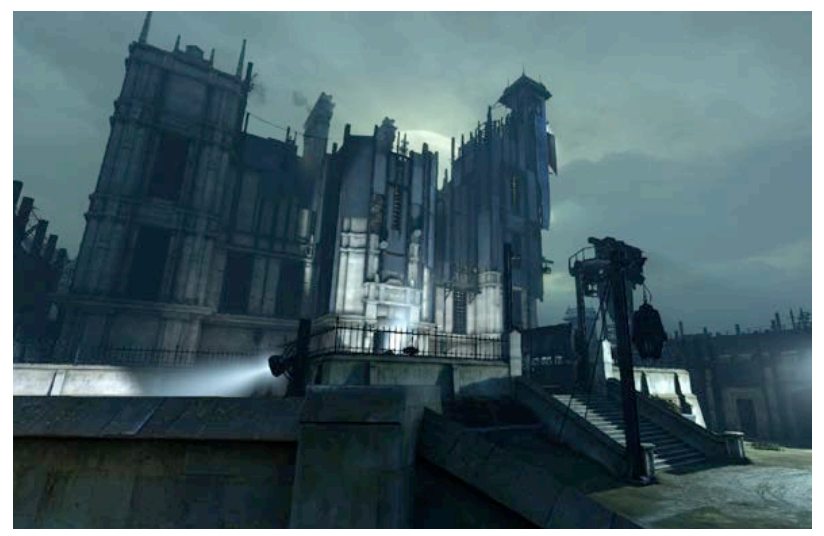

Figure 8 - Dunwall Tower following Hiram Burrows' rise to power. The lighting serves to emphasise the building's menacing visage.

\section{Dunwall Tower}

After Corvo has eliminated all but one of the members of the group who framed him, the final conspirator Lord Regent Hiram Burrows retreats into the seat of power of the ruler of Dunwall: Dunwall Tower. This location is seen twice during the game; during the prologue when the Empress is murdered and six months later in the sixth mission. Located on a cliff overlooking the Wrenhaven River and adjacent to Coldridge Prison, the castle-like structure is surrounded by large gardens and represents a departure from the dense residential and industrial architecture which is prevalent in Dunwall, emphasizing the authority and the historical dominance of the royal family. Its expression is an eclectic mix of real-world architectural styles, predominantly drawing features from English Gothic architecture, particularly the Perpendicular Gothic period - though ornamental elements such as vaults and arches are absent in favour of a Modernist rectilinear articulation. The grand staircase leading towards the entry is reminiscent of Renaissance architecture, such as the Giants' Staircase leading into the Doge's Palace in Venice. The formal architectural design has few embellishments save for the openwork parapets foregrounding domes which surmount the outermost towers. Unlike the exaggerated decadence of Boyle Mansion (see Figures 9 and 10), the architecture is (comparatively) steadfast yet assertive and - in the prologue - works to express the sovereignty of the Empress without belittling the plight of the working class.

After the Empress is murdered, Burrows takes her place as ruler. In contrast to his predecessor, Burrows 'blames the city's problems on the Empress and on the laziness and disorder of the common people', and it is revealed through an audio recording in this mission that it was his idea to introduce the plague to the city. Dunwall Tower is transformed during his rule (see Figure 8), being heavily clad with jagged metallic structures (evocative of the works of architect Lebbeus Woods), along with watchtowers, spotlights and guard outposts. This architectural transformation - which does not happen elsewhere in the game as the player rarely visits locations multiple times - metaphorically represents the perversion of authority brought about by Burrows' morals and personality. The heavy fortifications symbolize the character's paranoia after all his allies have been eliminated by the player, converting Dunwall Tower into far more hostile architecture. In these and similar ways, architectural metaphor is pervasive in Dishonored 
and is utilized in a manner similar to its application in art, television and film, allowing information about the world and its characters to be inferred as a dynamic process as the player explores the location of each mission. Further than this, we would go on to argue that the bastardisation of the romantic-castle is resonant with Corvo's, and the player's, desire to avenge the empress.

\section{Societal Ethics}

Real-world architecture acts as a reflection of the history, culture and society of those it is designed by and built for (Ruskin, 1998, p. 274), and for coherency it must appear as though the same is true within a gameworld. This is to say that, where world-building is successful, game architecture will be an embodiment of the morals and values of the fictional people who inhabit it. As moral and ethical decisions are fundamental to gameplay in Dishonored, here we discuss the profound impacts that the architecture of the game has on the ethical experiences of the player within the gameworld and what Kristine Jørgensen (2015) refers to as the way Dishonored "plays ethical values against each other" (p. 218), by conveying the societal ethics and values of the gameworld to the player.

\section{The Distillery District and the Estate District}

Lady Boyle's Last Party, the fifth mission, tasks the player with eliminating Lady Boyle, the financier of the conspirators and mistress to the main antagonist. Before entering the Boyle Estate the player must traverse the surrounding streets of the upper-class Estate District (see Figure 11), which is portrayed in direct contrast to the lower-class Distillery District as seen earlier in the game (see Figure 12). While the architecture throughout both districts uses a predominantly Jacobethan (Jacobean revival) style as is typical throughout the city, differences in materiality, solar access and urban planning bring to light the extreme extent of social stratification in Dunwall. Geographically, the Estate District is at a higher elevation, symbolic of the aristocracy's elevated position over the lower class. In the Distillery District, the predominantly brick buildings are plastered with grime and graffiti, and all but a few entrances and shopfronts are barricaded. Upper levels are constricted by enormous snaking pipes and vents weaving between steel-framed balconies, haphazardly tacked on and cantilevering in all directions. In the densest areas the sky is barely visible, and the ground is illuminated only by small glimpses of moonlight and infrequently placed streetlamps.

By contrast, the Estate District features cleaner white masonry construction and a far less industrial aesthetic. While the street level is closed off due to the dangers of the rat plague, numerous lights in the windows of many of the buildings indicate that the residents remain, for the most part, unaffected by the plague. The steel structures which are appended to the buildings form bay windows are far more congruent with the Jacobethan style. The public domain is more generous and far less dense than the Distillery District, allowing the player to feel less confined as the entirety of the sky and surrounding cityscape is visible. Enormous floating lanterns and fireworks draw attention to the Boyle Mansion (see Figure 9), which irradiates an extravagance malapropos to the deteriorating state of Dunwall. The Queen Anne architectural style, evident from its stone quoins, painted sash windows and carved stone door-case, presents the mansion as superior even to the luxurious buildings which surround it. This excessive opulence continues through the Renaissance-styled interior architecture of the mansion (see Figure 10) and further highlights the significant discrepancy in economic and social status between the aristocrats and 


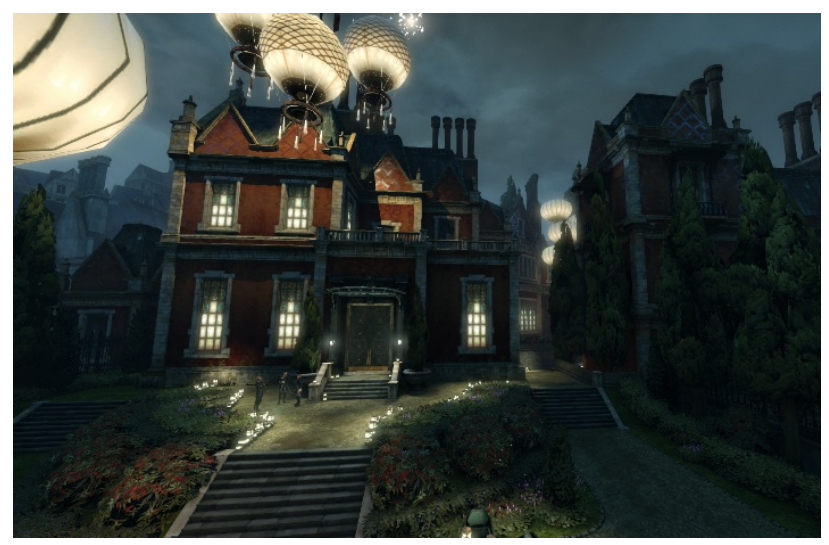

Figure 9 - The exterior Facade of the Boyle Mansion



Figure 11 - A view from the rooftop of a building in the estate district. Despite civil unrest and plague, the upper class still manages to enjoy the exuberance of a masquerade ball within the fortified walls of the Boyle estate.



Figure 10 - The intricate Renaissance-styled architectural detailing within the decadent Boyle mansion

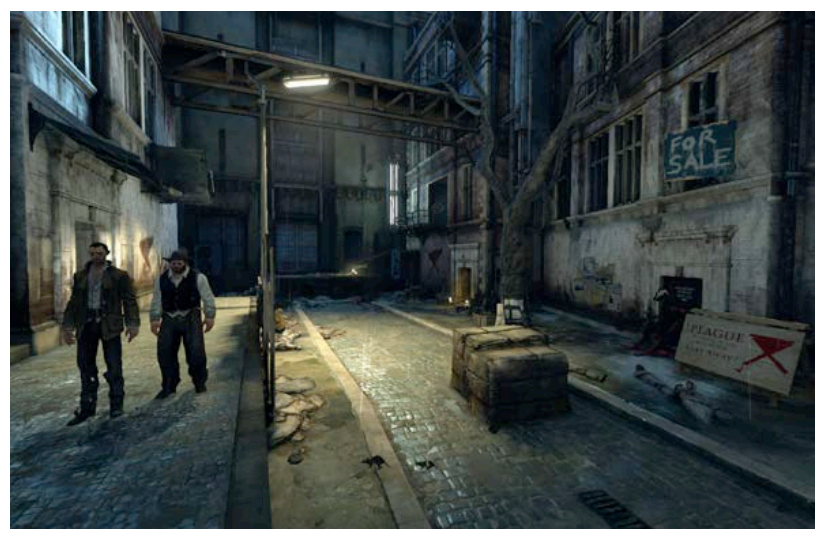

Figure 12: The streets of the Distillery District as seen by the player in an earlier mission, depicting the living conditions of the lower class.

the common citizens. Corvo's visit to the Estate District takes place immediately following a long period spent in the slums and ruined districts of Dunwall, forcing a juxtaposition between the two areas that acts as a resource for the player - an ethical agent (Sicart, 2008) - to reflect upon the nature and ethics of their acts within the gameworld. This is further reinforced by the game's conceptual influence of "the contrast in every city between its logical renaissance structure and the chaos that lies underneath, that nobody sees" (Antonov \& Zeller, 2012, p. 170).

Infrastructural historical reference to late nineteenth century London's social class division (Jones, 1971), which was divided similarly into the East and West ends, is embodied in Dunwall's economically and socially divergent district architecture. Here then, architecture paints the ethical framework of Dunwall, creating a dystopian environment against which the player can reflect upon the moral nature of their acts within the gameworld. The juxtaposition between these districts works along with the other techniques identified by Jørgensen (2015) to tempt "the player to give in to vengeance" and engage in dark play (p. 221); all assassination 
targets are part of this decadent, and immoral, upper class. To recast this analysis to thinking about how the architecture of Dishonored constructs the player-character, we might consider how Corvo's base for recuperation is the run-down and empty Old Port District. He belongs (and therefore, the player belongs) to these lower-class spaces and moral motivations.

\section{The Flooded District}

Following his second betrayal - this time by his apparent allies - Corvo is left for dead in the Flooded District. Previously a prosperous financial district, the area was flooded when water barriers collapsed due to lack of maintenance, after the outbreak of the rat plague but before the events of the game. The player must escape this hostile zone to reach their goal, navigating through submerged warehouses and the ruins of a condemned district. The architecture of the area tends to follow the styles seen previously in the game, with the vast majority of the buildings taking on a synthesized industrial-Jacobethan aesthetic. The impact on the player, however, lies in how the architecture is framed. Instead of being embedded with information regarding human forces at work in the world of Dishonored, the floodwaters and crumbling facades gesture towards the destructive forces of nature and time which lie outside of human control. In the first half of the mission, the player must swim, climb and tunnel through the waterlogged remains of the Rudshore Waterfront (see Figure 13). The architecture tells stories of those who once lived here, with walls of apartments crumbling away to reveal traces of their previous inhabitants frozen in time (see Figure 14).

Architectural ruins have specific connotations and deep history in art and architectural discourse. As Paul Zucker (1961) notes "ruins have held for a long time a unique position in the visual, emotional, and literary imagery of man" (p. 120). They represent "a combination of man-made forms and of organic nature. Thus the emotional impact of ruins is ambiguous: we cannot say whether they belong aesthetically in the realm of art or in the realm of nature" (p. 120). Even videogame ruins, which have only ever existed in their destroyed state, work to evoke a historical perspective in the world-building of Dishonored. Ruins in games can be used as "modular units of complex meaning" (Fraser, 2015, p.13) which the player can engage with through exploration (Fraser, 2016). Emma Fraser (2015) asserts that "the use of ruins in games is deeply entwined with the generation of meaning through the structures of play, production of space, and use of visually communicative content" (p.3). There is a suggestion that these spaces were once inhabited by fictional characters, as richly fleshed out as the main characters in the game. While none of these unseen characters are made explicit to the player (aside from the odd journal or note which can be found lying around), past experiences and interactions in the game fill in the blanks, forming backstories and narratives which exist only in the mind of the player yet begin to enrich and realize the gameworld. This infers that architecture can be embedded with not only real-world infrastructures (as previously discussed) but gameworld infrastructures as well.

The dystopian ruined architecture of Dunwall, observable most explicitly through the player's exploration in the Flooded District, can only ever be experienced and viewed in its ruined state. As the history and events prior to the game's opening are pre-established, the player has no influence on how the city reached this state of dystopia. However, the moral decisions made by the player throughout the game's narrative - influenced by their perceptions of the gameworld conveyed through the game's various world-building techniques - can influence how the game ends: the player is afforded the opportunity to influence the future of Dunwall through their 




Figure 13 - Submerged warehouses and refineries litter the Rudshore Waterfront in the Flooded District, inhabited only by hostile river creatures and infected plague victims.

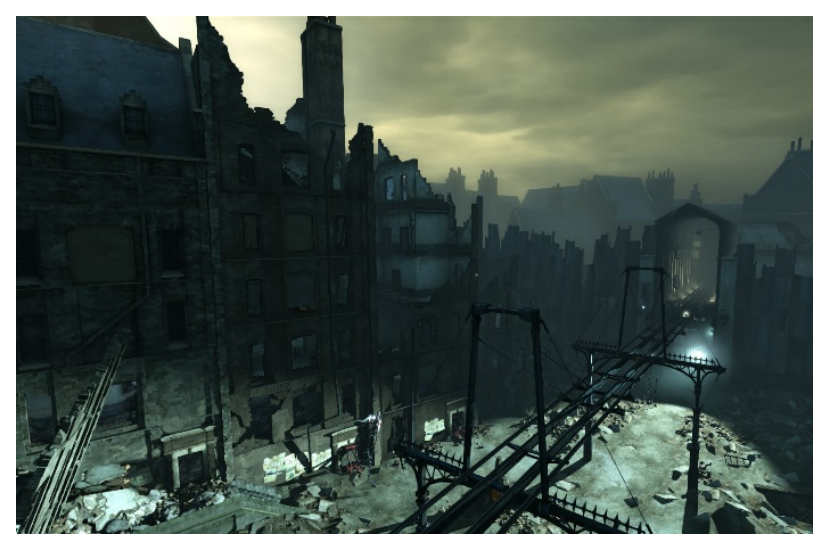

Figure 14 - Ruins in the condemned Flooded District, where very few survivors hide from the City Watch. The train tracks are used to transport and dump the bodies of plague victims.

choices. In low chaos, the ending shows Emily Kaldwin rising to the throne as a benevolent and loved ruler, bringing the city of Dunwall back from the brink of destruction into a golden age as a cure for the rat plague is developed. Conversely in high chaos, Emily will either begin a sadistic reign of terror influenced by Corvo's violent actions or be absent completely if she died in the final mission. In this case the ending shows the rest of Dunwall being decimated by the plague as Corvo flees the city on an outbound ship. The horrors of the plague experienced in the Flooded District provoke moral reflections on the consequences and influence of the player's actions. Fraser (2015) notes that "the dimension of exploration is one way in which the visual or surface content of ruins-in-games moves beyond the symbolic to shape activities that may impact or facilitate gameplay" (p.26); in this instance, we argue that it impacts the player's role as an ethical agent. Architecture in Dishonored works to shape the player's ethical agency through their interactions and observations in Dunwall by providing motivation (or deterrence, depending on their moral code) to redeem the city and save the lives of the citizens of Dunwall.

\section{On Bodies, Playstyle and Architecture}

As part of the methodology for conducting this close analysis, the game was played through twice, completely, in Dishonored's two (often opposite) ways of completing the game: lowchaos and high-chaos. These two playthroughs necessitated two distinct playstyles. Low chaos required significantly more stealth to remain undetected as hostile encounters were precluded by the methodology, but high chaos allowed more reckless and aggressive gameplay. The goal of this was to determine whether the architecture differed between the two, as other elements of the game do change based on the player's choices. Aside from minor differences in the final mission (additional guard towers), we identified no architectural changes from the different chaos-states.

However, this allowed us to observe the way that Dishonored's architecture played a more prominent role when playing stealthily as opposed to confrontationally (see Figure 15), highlighting the role that the virtual embodiment plays in our experience of virtual space (Grosz, 2001, pp. 75-89). While the focus of our visual analysis was on the design of buildings and streetscapes, we found that during stealthy play, greater attention was paid towards architectural features such as ledges, fenestration, balconies, exposed structures and undercrofts as they 


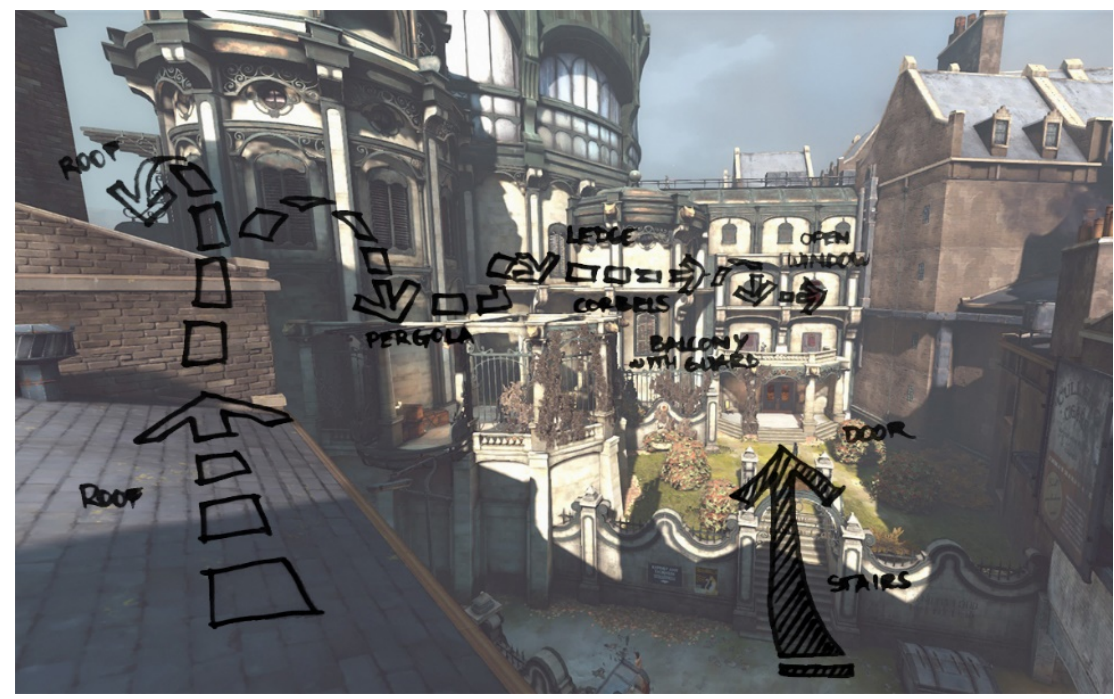

Figure 15 - A sketch showing two potential pathways into one of the buildings Corvo must infiltrate. A stealthy approach shown in dashed arrows requires the player to consider and be aware of architectural features far more than the confrontational approach shown in a solid arrow.

facilitated alternative pathways to the goal which were unseen by patrolling enemies. For instance, the horizontal lines in the architecture of the Office of the High Overseer played a functional as well as intertextual role in the game as they afford Corvo the means to scale and traverse the building with ease, unlike the unreachable ceiling spaces of Coldridge Prison and its uninterrupted vertical. In this way, the architecture in this first assassination mission works to ensure the player feels as though they have overcome the helplessness that they experienced in the prison. When playing in high Chaos, however, play was typically characterized by simply charging down the middle of an area killing everyone in the path, while paying little to no attention to the surrounding environment or architecture (this playthrough also took significantly less time to complete).

While videogame space has been more deeply theorized and discussed elsewhere (Aarseth, 2001; Wolf, 2011), it is worth noting that the representations of space in games are not, in themselves, "spatial, but symbolic and rule-based"; they are "means to achieve the object of gameplay" (Aarseth 2001, p. 163), or in this case the particular gameplay experiences of stealth and puzzle. The differences described above have been previously identified by Marc Bonner (2015), who notes that "stealth gameplay means sneaking around the enemies, using architecture and environment as cover" but that during action gameplay "architecture is reduced to a system of cover possibilities" (p. 7). Although our analysis has focused on Dishonored's architecture as a visual art, this emphasizes how a game's-built environment (in this case, its architectural style) is deeply connected with the player's embodiment in the gameworld (the character of Corvo). Elizabeth Grosz (2001) has previously criticized the tendency of theorists to view "VR and cyberspace ... as spaces of disembodiment and thus a new kind of space unconstrained by the limits of corporeality" (p. 81), which we argue would also be an unproductive approach to understanding the relationship between player experience and the architecture of the gameworld. Not only does the architecture of the gameworld become an extension of the player's expertise and prowess, but it makes possible the very experience of becoming embodied in the gameworld. 
This approach is situated within Bonner's (2015) conceptualizations of game-architecture as a form of lived space (channeling Pallasmaa, 2012), as it was through the playstyle-based traversal of the architecture that many of our inferences were drawn. While Aarseth (2001) notes that our experience of in-game architectures is "dependent on our bodily experience in, and of, real spaces" (p. 162) it is evident then that it is also dependent on our embodied experience of these virtual spaces. The player's interpretation of the horizontal line in the Office of the High Overseer is not simply metaphorical, but one constituted by the embodied and interactive nature of traversing the space stealthily. To describe, as we do earlier, the fortification of Dunwall Tower as hostile is not just based on our 'real' bodily experience of sharp, metal objects as hostile, but also our embodied experience as our avatar Corvo, unable and unafforded to traverse across the pointed ironwork. Drawing on examples from Assassins Creed Unity, Bonner (2015) gives the example of how the isolated places on top of bell towers are both at one rewarding vistas (to view the city) and refuge spaces (to escape pursuing guards) (p. 10). If the player could attain the supernatural ability to ignore these types of barriers or to explore the gameworld as a tourist rather than assassin, the architectural space of the game would have a different impact on player experience. While methods for analyzing architecture in film and television are well established (see Fear, 2000), analyses of architecture in games - and how architecture impacts player experience - must consider the playstyles supported by the game, the affordances of architecture as navigable by the player's corporeal, material virtual-body (Grosz, 2001), as well as how the architecture of the game works, in turn, to construct the identity of the player and non-player characters (Massey, 1994).

\section{Discussion \& Conclusion}

In this article, we have presented a close analysis of the architecture in Dishonored, focusing on its visual elements, demonstrating how the game's varied but coherent architecture works to shape and inform the player's knowledge of the rich gameworld. Through various intertextual allusions and metaphorical representations, the architecture works as a storytelling element, contextualizing information that the player learns and conveying important information about the game's main characters, similar to the ways that architecture is utilized in other visual media such as television and film. Beyond prior work, we have also suggested in this article that the architecture in Dishonored plays a crucial role in conveying to the player information about the morals and values of the fictional society, an additional way in which the game "plays ethical values against each other" (Jørgensen, 2015, p. 218).

While examples such as those presented by von Borries et al. (2007), Walz (2010) and Bonner (2014) have drawn attention to the ways architectural theory can be constructively brought to the study and theorization about videogames, in this article we have uniquely presented a detailed analysis of the breadth of architectural styles and forms within a single videogame. While Bonner provides $(2014$; 2015) similar, although brief, analyses, this paper is a comprehensive expansion upon the framework he established to understand in detail (one of) the functions of architecture in gameplay experiences. In doing so, we also expand greatly upon Wolf's (2014) recognition of architecture as an infrastructural facet in world-building, lending significant weight to the claim that architecture is indeed important to both game scholars and designers (Esklinen, 2004). 
An additional contribution of this work has been to highlight the relationship between gameworld ethics and architecture, which has not previously been established in the (albeit limited) literature. This allows us to link the role of game architecture in player experience to the concept of players as ethical agents; that is, that a player is "morally aware and capable of reflecting upon the nature of her acts within the game world" (Sicart, 2011, p. 62). While Kristine Jørgensen (2015) has previously analyzed the ways that the missions, narrative and consequences in Dishonored push the player towards 'dark play' (2015), there is no reference to architecture, instead focusing on ethical frameworks around player actions rather than anything physically manifest in the gameworld. Our results demonstrate the similar function that the game's architecture plays in establishing this ethical tension that is core to the appeal of the Dishonored series.

As we have noted, our approach - which draws on traditions of visual analysis of architecture in film (see Fear, 2000; Tobe, 2016) - is limited by its focus on the visual, intertextual and metaphorical aspects of Dishonored's architecture. In our reflections on playstyle, we draw on Bonner (2015) to note the way that the different embodied approaches to the gameworld (stealthily, or violently) impact upon our experience of the game's architecture. Our encounters with these virtual spaces are, crucially, interdependent on our virtual bodies (following Grosz, 2001). While such an approach has been fruitful here for understanding and unpacking how the imaginary world of Dishonored is constructed and experienced by players, future work should further consider how all the avatars, characters and players (Carter et al. 2012) within a game world are constructed by its architecture, and how other dimensions such as race and gender (Massey, 1994; Neely \& Samura, 2009) might impact the embodied experience of architecture in gameworlds.

\section{References}

2K Boston (2007). BioShock. SK Games: Californa, USA.

Aarseth, E. (2001). Allegories of space. The question of spatiality in Computer Games. In M. Eskelinen \& R. Koskimaa (Eds.), Cybertext yearbook 2000 (pp.152-171).

Antonov, V., Mitton, S. \& Baron, J. L. (2012). Behind the scenes of Dishonored: An interview with the creators of the epic dystopian game. Vice Creators. Retrieved September 30, 2017 from https:/creators.vice.com/en_us/article/behind-the-scenes-of-idishonoredi-aninterview-with-the-creators-of-the-epic-dystopian-game.

Antonov, V. \& Zeller, O. (2012). Doing entire worlds: Viktor Antonov reveals his motivations as a designer of fictional worlds. MARK, Another Architecture, 40(1).

Arkane Studios (2012). Dishonored. Bethesda Softworks: Lyon, France.

Arkane Studios (2016). Dishonored 2. Bethesda Softworks: Lyon. France.

Arkane Studios (2017). Dishonored: Death of the Outsider. Bethesda Softworks: Lyon, France.

Björk, S., \& Holopainen, J. (2005). Patterns in game design. Hingham, Mass.: Charles River Media.

Bonner, M. (2014). Analyzing the correlation of game worlds and built reality: Depiction, function and mediality of architecture and urban landscapes. In Proceedings of DiGRA 2014. Atlanta, Georgia: DiGRA. 
Bonner, M. (2015). Ambiguous play pattern: A philosophical approach to the prospect-refuge theory in urban open world games by merging Deluze/Guattari and de Certeau. Paper presented at the Philosophy of Computer Games Conference 2015: Meaning and Computer Games. Berlin, Germany.

Carter, M., Gibbs, M. \& Arnold, M. (2012). Avatars, characters, players and users: multiple identities at/in play. In Proceedings of the $24^{\text {th }}$ Australian Computer-Human Interaction Conference (pp. 68-71). ACM Press,

Egenfeldt-Nielsen, S., Smith, J. H., \& Tosca, S. (2008). Understanding videogames: The essential introduction. London: Routledge.

Eidos Montréal (2011). Deus Ex: Human Revolution. Square Enix: Tokyo, Japan.

Eskelinen, M. (2004). Markku Eskelinen's response. Electronic Book Review. Retrieved from http://electronicbookreview.com/thread/firstperson/astragalian

Fear, B. (2000). Architecture + film II. London: Academy Press.

Flynn, B. (2004). Games as inhabited spaces. Media International Australia, 110(1), 52-61.

Fraser, E. (2015). Ruin representations: Understanding meaning making in video games through urban ruins, allegory and trope theory. Paper presented at the Philosophy of Computer Games Conference 2015: Meaning and Computer Games. Berlin, Germany.

Fraser, E. (2016). Awakening in ruins: The virtual spectacle of the end of the city in video games. Journal of Gaming and Virtual Worlds, 8(2), 177-196.

Grinceri, D. (2016). Architecture as cultural and political discourse: Case studies of conceptual norms and aesthetic practices. London: Routledge.

Grosz, E. (2001). Architecture from the outside: Essays on virtual and real space. Cambridge, MA.: MIT Press.

Golding, D. (2013). Putting the player back in their place: Spatial analysis from below. Journal of Gaming \& Virtual Worlds, 5(2), 117-130.

Jenkins, H. (2004). Game design as narrative architecture. In N. Wardrip-Fruin \& P. Harrigan (Eds.), First person: New media as story, performance, and game (pp. 118-130). Cambridge, MA.: MIT Press.

Jones, G. S. (1971). Outcast London: A study in the relationship between classes in Victorian society. Oxford: Oxford University Press.

Jørgensen, J. (2013). Gameworld interfaces. Cambridge: MIT Press.

Jørgensen, K. (2015). Dark play in Dishonored. In T. Mortensen, J. Linderoth \& A. Brown (Eds.), The dark side of game play: Controversial issues in playful environments (pp. 210-225). London: Routledge.

Klastrup, L. (2009). The worldness of Everquest: Exploring a $21^{\text {st }}$ century fiction. Game Studies, 9(1). Retrieved from http://gamestudies.org/0901/articles/klastrup.

Krzywinska, T. (2008). World creation and lore: World of Warcraft as rich text. In H. G. Corneliussen \& J. W. Rettberg (Eds.), Digital culture, play and identity: A world of warcraft reader (pp. 123-142). Cambridge: MIT Press.

Lamster, M. (2000). Architecture and film. New York: Princeton Architectural Press.

Massey, D. (1994). Space, place and gender. Minneapolis, MN.: University of Minnesota Press.

Neely, B. \& Samura, M. (2011). Social geographies of race: Connecting race and space. Ethnic and Racial Studies, 34(11), 1933-1952.

Nitsche, M. (2008). Video game spaces: Image, play and structure in 3D worlds. Cambridge: MIT Press. 
Pallasmaa, J. (2012). The eye of the skin: Architecture and the senses. Chichester: John Wiley \& Sons Ltd.

Ruskin, J. (1998). Traffic. In J. D. Rosenberg (Ed.), The genius of John Ruskin: Selections from his writings. Charlottesville: University of Virginia Press.

Smith, H. (2016). --> Hello, I'm Harvey Smith <----> Dishonored 2 AMA <--. Retrieved October 2, 2017 from

https://www.reddit.com/r/dishonored/comments/5ax8f1/hello_im_harvey_smith_dishono red 2 ama/.

Sicart, M. (2009). The ethics of computer games. Cambridge: MIT Press.

Skinner, S. (2009). Sacred geometry: Deciphering the code. New York: Sterling Publishing.

Tanenbaum, J., Tanenbaum, K., \& Wakkary, R. (2012). Steampunk as design fiction. In Proceedings of the SIGCHI Conference on Human Factors in Computing Systems (pp. 1583-1592). ACM Press.

Tobe, R. (2016). Film, architecture and spatial imagination. London: Routledge.

Valve Corporation (2004). Half Life 2. Valve Corporation: Washington, USA.

von Borries, F., Walz, S., \& Böttger, M. (2007). Space time play: Computer games, architecture and urbanism. Basel: Birkhäuser Verlag.

Walz, S. (2010). Towards a ludic architecture. Pittsburgh: ETC Press.

Wesp, E. (2014). A too-coherent world: Game studies and the myth of "narrative" media. Game Studies, 14(2). Retrieved from http://gamestudies.org/1402/articles/wesp

Wolf, M. J. P. (2012). Theorizing navigable space in videogames. In DiGAREC KeynoteLectures 2009/10. S. Gunzel, M. Liebe \& D. Mersch (Eds.) (pp. 18-48). DiGAREC Series 06, Potsdam University Press.

Wolf, M. J. P. (2012). Building imaginary worlds: The theory and history of subcreation. London: Routledge.

Yin, R. (2003). Case study research: Design and methods, vol. 5. London: SAGE Publications. 